\title{
Design of Automatic Loading Machine in Electroplating Industry
}

\author{
Jay M. Malpani ${ }^{1}$, Kaustubh G. Kulkarni ${ }^{2}$ \\ School of Mechanical Engineering, \\ Dr. Vishwanath Karad MIT World Peace University, \\ Pune, India
}

\begin{abstract}
Earlier, in electroplating industries, all the work was done manually. In 1976, the first semi-automatic plant was set up in India. Thus the electroplating industry has taken a big jump after the introduction of automatic plants. However, there are some tasks which are still being done manually and result in more use of labour leading to inefficiency and tedious work. One of these tasks is loading of barrel. This paper includes the design of automatic loading machine and various components required for the automatic weighing and loading of material into the barrel. It also includes the financial cost analysis of the machine and thus, the break even time of the machine. It concludes with the benefits of using this automatic loading machine over manual loading.
\end{abstract}

Keywords: Electroplating, material, loading, barrel, cost

\section{INTRODUCTION}

A. Field

Metals are predominantly being used in almost every aspect of our day to day lives. However, one of the major problems in metals is corrosion i.e. gradual destruction of metal by oxidation i.e. chemical reaction with oxygen present in the environment. Thus, a special branch called corrosion engineering has been designed to study the prevention of corrosion. Especially, in automobiles, the chances of metal parts getting corroded are high due to the working conditions. The most widely used method for prevention of corrosion in automobiles is plating. Plating is a surface coating chemical process in which a metal is deposited on another metal having a conductive surface.

Plating is one of the major processes in corrosion resistance. The advantages of plating include:

- Protection from corrosion

- Appearance

- Superior Hardness and Better Wear Resistance

\section{B. Background}

An electroplating process involves a series of chemical reactions with different chemicals to achieve the final result. In industries, these reactions take place in tanks containing the chemicals. The parts that need to be plated need to be kept in one tank for a decided amount of time in which the reaction takes place. After a particular reaction it needs to be transferred from one tank. This process continues until the last tank is reached and all chemical reactions have taken place.

The two types of electroplating industries include:

1) Manual Plant: Manual plant is a plant in which transfer of work between tanks is by hands. The parts are immersed in tanks manually and held for a particular period of time before transferring to next tank.

2) Automatic Plant: An automatic plating plant is a line of process tanks with a transfer system which enables the parts to be plated to be immersed in each tank for the appropriate time and in the sequence necessary to produce the required finish.

C. Scope

Manpower is a major factor in any industry. However excessive use of manpower can lead to reduction in efficiency, increase in total production cost due to salary of manpower, decrease in production and inconsistent quality. In many industries, one more important requirement is skilled labour. Also, the salaries of labour are increasing every year due to inflation. Thus, the main aim in any industry in today's world is to reduce manpower and introduce the use of machines wherever possible to increase the efficiency of working.

These issues can be taken care of by conversion of manual plating plant to automatic. However, even in automatic plants, the loading and unloading of parts on barrel takes place manually. At one time, $100 \mathrm{~kg}$ of material is to be weighed and loaded which is a very tedious task. This results in increase in labour and thus decreases the efficiency. Thus, one more major problem is how to transform manual loading of barrels to automatic loading in an automatic plating plant.

\section{AUTOMATIC LOADING MACHINE}

The Automatic Loading Machine is intended to give an output of a pre-defined quantity of material as per the set weight. Electroplating is a surface treatment phenomenon based on the surface area of the material. However surface area of a material is very difficult to measure. This surface area can be converted to weight by a suitable conversion factor obtained experimentally. Thus the required output can be achieved by setting a weight limit. Thus, the Automatic Loading Machine transports the component to the height of the barrel and loads the material according to the weight.

\section{A. Construction}

The Automatic Loading Machine can be divided into two sections:

1) Loading Conveyor Section

This section transfers the material from bottom to the height at which it has to be loaded in the barrel. It consists of:

- Hooper: It is used to store the material which has to be loaded on the barrel before transportation by the conveyor. 
It is a storage tank/pit located at the one end of the conveyor.

- Slat Belt: It is the belt of the conveyor section which is used to transfer materials to the other end located at the top. This belt is further divided into compartments to facilitate lifting and transfer of material.

- Conveyor Roller: It is used to run the slat belt. The roller is powered by gear box which is powered by the motor. Thus the roller runs the slat belt with a speed according to our requirements.

- Motor: Motor gives required power to the gear box which is used to run the roller.

- Gear Box: It is used for reduction of the speed and increase in torque received by the motor according to requirement of the belt.

2) Weighing and Transfer Trolley Section

This section does the weighing of the material and actual loading to the barrel by pneumatic push. It consists of:
- Pneumatic Cylinder: The cylinder is used to push the trolley forward towards the barrel for loading. When it receives a signal from the system it is actuated.

- Solenoid Valve: When the weight limit is reached, the signals given to stop the belt and start the cylinder are actuated by solenoid valves.

- Load Cell: It is located inside the trolley and is used to weigh the material entering the trolley. Once the weight limit is reached the system sends signals to conveyor to stop and pneumatic cylinder to start

- Trolley: The trolley is used to transfer the material from the receiving point to distance where it is loaded onto the barrel. The shape of the trolley facilitates direct transfer of material to the barrel.

- Compressor: It is used to supply compressed air for actuating the cylinder. The compressor is also used for various other processes like drying in an electroplating industry.

TABLE I. SPECIFICATIONS OF COMPONENTS OF AUTOMATIC LOADING MACHINE

\begin{tabular}{|c|c|c|c|c|}
\hline \multicolumn{5}{|c|}{ Conveyor Section } \\
\hline Sr.No. & Part & Selection Basis & Parameters & Value / Type \\
\hline \multirow[t]{6}{*}{1} & \multirow[t]{6}{*}{ Hooper } & \multirow[t]{6}{*}{ Capacity of Material to be stored } & Material & Mild Steel \\
\hline & & & Length & $1200 \mathrm{~mm}$ \\
\hline & & & Width & $1000 \mathrm{~mm}$ \\
\hline & & & Height & $1000 \mathrm{~mm}$ \\
\hline & & & Thickness & $5 \mathrm{~mm}$ \\
\hline & & & Storage Capacity & $600 \mathrm{~kg}$ \\
\hline \multirow[t]{7}{*}{2} & \multirow{7}{*}{ Slat Belt } & \multirow{7}{*}{ Available Space } & Total distance & $3600 \mathrm{~mm}$ \\
\hline & & & Length & $7200 \mathrm{~mm}$ \\
\hline & & & Width & $450 \mathrm{~mm}$ \\
\hline & & & Thickness & $10 \mathrm{~mm}$ \\
\hline & & & Number & 2 \\
\hline & & & Material & Mild Steel \\
\hline & & & Number of Compartments & 8 \\
\hline \multirow[t]{3}{*}{3} & \multirow[t]{3}{*}{ Conveyor Roller } & \multirow[t]{3}{*}{ Dimensions of Belt } & Diameter & $150 \mathrm{~mm}$ \\
\hline & & & Length & $450 \mathrm{~mm}$ \\
\hline & & & Material & Mild Steel \\
\hline \multirow[t]{2}{*}{4} & \multirow[t]{2}{*}{ Motor } & \multirow[t]{2}{*}{ Calculations for selection of motor } & Power Rating & $1.5 \mathrm{HP}$ \\
\hline & & & Rated RPM & $960 \mathrm{RPM}$ \\
\hline 5 & Gear Box & Available Motor Specifications & Gear Ratio & 36 \\
\hline
\end{tabular}

\begin{tabular}{|c|c|c|c|c|}
\hline \multicolumn{5}{|c|}{ Weighing and Transfer Trolley Section } \\
\hline Sr.No. & Part & Selection Basis & Parameters & Value / Type \\
\hline \multirow[t]{3}{*}{1} & \multirow[t]{3}{*}{ Pneumatic Cylinder } & \multirow[t]{3}{*}{ Calculations for selection of cylinder } & Bore Diameter & $54 \mathrm{~mm}$ \\
\hline & & & Rod Diameter & $20 \mathrm{~mm}$ \\
\hline & & & Stroke Length & $1000 \mathrm{~mm}$ \\
\hline \multirow[t]{2}{*}{2} & \multirow[t]{2}{*}{ Pneumatic Solenoid } & \multirow[t]{2}{*}{ Standard specifications available } & Type 1 & 5/3 Solenoid Valve \\
\hline & & & Type 2 & 5/2 Solenoid Valve \\
\hline 3 & Load Cell & Required output weight & Capacity & $1500 \mathrm{~mm}$ \\
\hline \multirow[t]{6}{*}{4} & \multirow[t]{6}{*}{ Trolley } & \multirow[t]{6}{*}{ Capacity of material to be loaded } & Material & Mild Steel \\
\hline & & & Length & $700 \mathrm{~mm}$ \\
\hline & & & Width & $600 \mathrm{~mm}$ \\
\hline & & & Height & $450 \mathrm{~mm}$ \\
\hline & & & Thickness & $5 \mathrm{~mm}$ \\
\hline & & & Capacity & 150 \\
\hline \multirow[t]{2}{*}{5} & \multirow[t]{2}{*}{ Compressor } & \multirow[t]{2}{*}{ Required discharge pressure } & Power Rating & $10 \mathrm{HP}$ \\
\hline & & & Discharge Pressure & bai \\
\hline
\end{tabular}




\section{B. CAD Drawing}

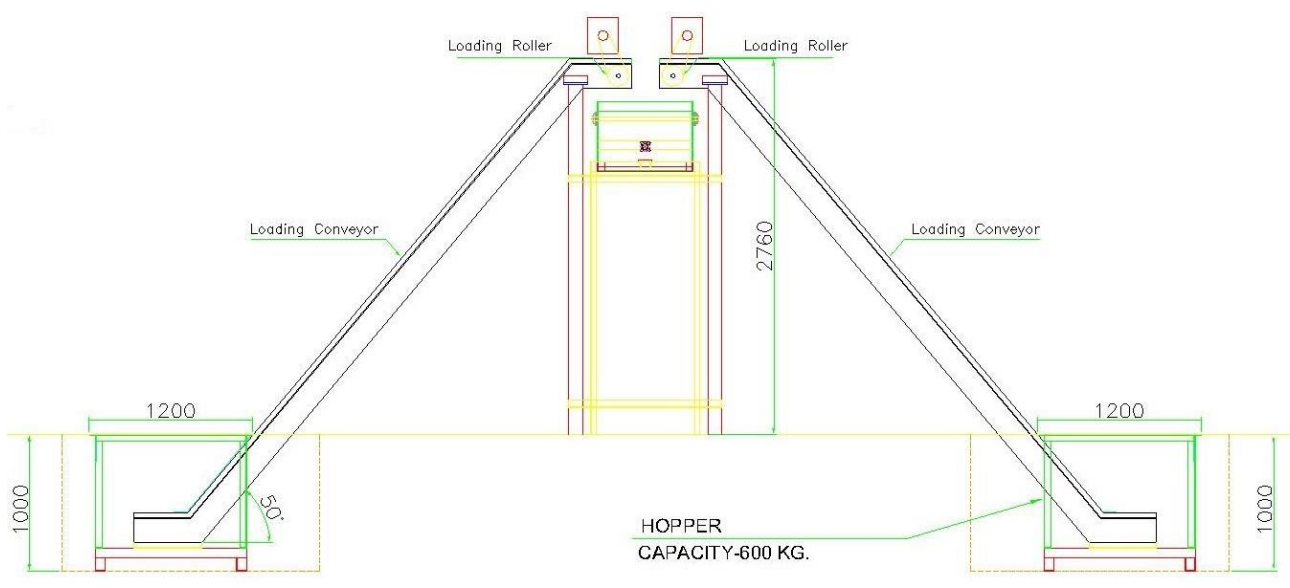

Fig. 1. Front view of Machine

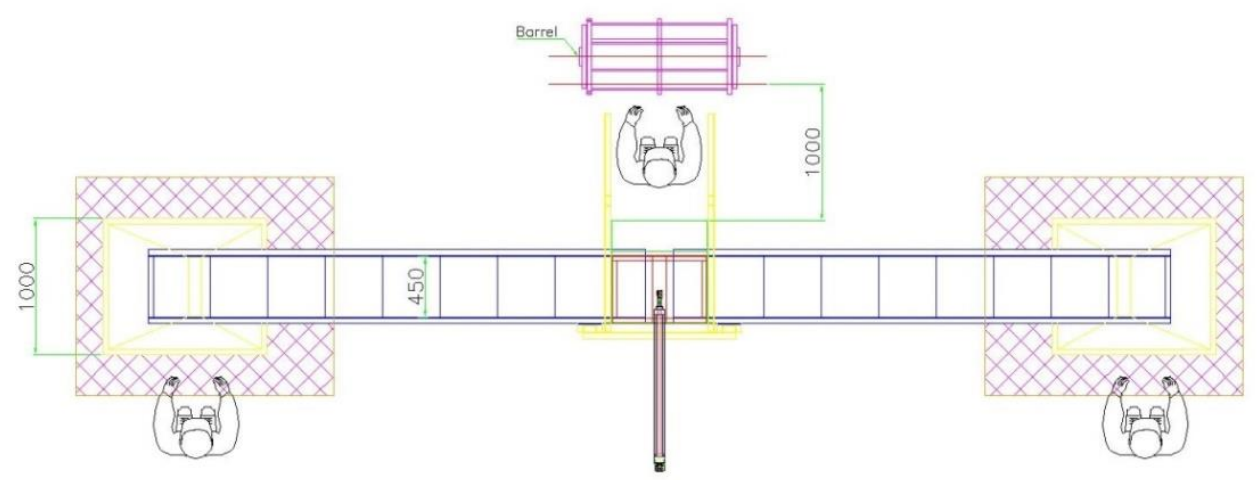

Fig. 2. Top view of Machine

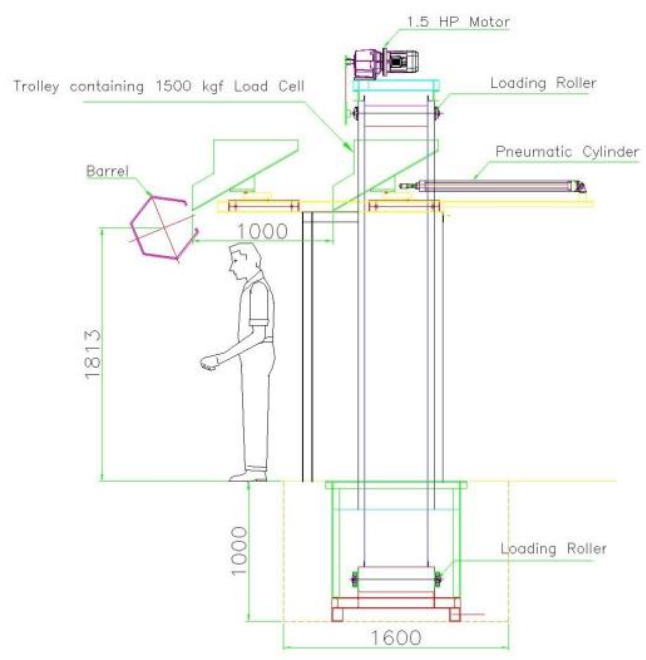

Fig. 3. Side view of Machine

\section{Working}

The working of the Automatic Loading Machine can also be divided as per two sections:

\section{1) Loading Conveyor Section}

The material which is received is transported to the hooper manually. The conveyor belt which runs on the rollers, collects the material from the hooper in different compartments. The material collected in each compartment is calculated by experimentation. The rollers are powered by the gearbox, which is eventually powered by the motor. These materials are transferred to a height at which barrel is placed and then transferred into a trolley

2) Weighing and Transfer Trolley Section

The material placed in the trolley is weighed by using load cell. When the weight reaches the set limit, the system gives a signal to switch off the motor and stop the conveyor. It also actuates the pneumatic cylinder by the solenoid valve to push the trolley forward. The material is carried forward by the trolley thus emptied in the barrel and taken for further processing. 


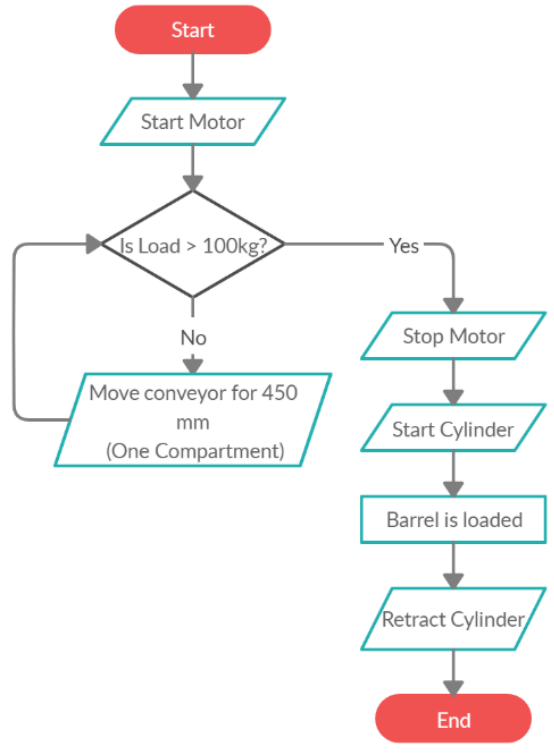

Fig.4. Flowchart showing working of automatic loading machine

\section{CALCULATIONS}

\section{A. Selection of Motor}

\section{1) Motor RPM}

Electroplating is a surface treatment phenomenon. Therefore, the capacity of barrel depends on surface area. Each barrel has a capacity of electroplating 100sq.ft. material. However, as mentioned above it is difficult to measure surface area. Thus, this surface area is converted to weight using a suitable factor which is obtained experimentally.

The surface area of one part is measured and various such parts are placed in a vessel whose weight is measured. This is how the weight can be found. According to industry standards, the conversion factor is considered as 1 sq.ft. $=1$ $\mathrm{kg}$.

Thus, capacity of the barrel is $100 \mathrm{~kg}$. Loading is done every minute. Therefore, output required is $1 \mathrm{~kg} / \mathrm{min}$.

To find the effective loading, we need to find the volume of each compartment and thus find the mass in it.

Volume of each compartment can be found as,

Length of each compartment $=1_{\text {comparment }}=450 \mathrm{~mm}$

Breadth of each compartment $=b_{\text {comparment }}=450 \mathrm{~mm}$

Height of each compartment $=\mathrm{h}_{\text {comparment }}=40 \mathrm{~mm}$

Therefore, Volume of each compartment

$\mathrm{V}_{\text {comparment }}=1_{\text {comparment }} \times \mathrm{b}_{\text {comparment }} \times \mathrm{h}_{\text {comparment }}=$ $8100000 \mathrm{~mm}^{3}=8.1$ litre

$\left(1\right.$ litre $\left.=1000000 \mathrm{~mm}^{3}\right)$

Another experiment is performed to find the weight of material occupied in a 1 litre vessel. It is found from this experiment that a 1 litre vessel occupies $3 \mathrm{~kg}$ of material. This value is different for different parts.

Also, due to the shape of the part, when the conveyor moves up, it cannot occupy its complete volume with material. According to industry standards and experiments conducted, it is found that around $50 \%$ of each compartment of the belt can be loaded.

Therefore, effective loading of each compartment can be found as, $\mathrm{m}_{\text {effective }}=\mathrm{V}_{\text {compartment }} \times$ Conversion factor $\times$ Effective loading factor $=12.15 \mathrm{~kg}$

There are 8 compartments of $450 \mathrm{~mm}$ length present on the 3.6 meter belt. Therefore, total mass of all material,

$\mathrm{m}_{\text {material }}=\mathrm{m}_{\text {effective }} \times$ No. of compartments $=97.2 \mathrm{~kg}$

$\mathrm{m}_{\text {material }}=100 \mathrm{~kg}$ (approx.)

Therefore, time required for loading of material can be calculated as,

$\mathrm{t}=$ Output required $(\mathrm{kg} / \mathrm{min}) /$ Input mass of material

$=1 \mathrm{~min}=60 \mathrm{sec}$

Therefore, in this time the whole belt needs to move up, thus distance travelled will be equal to length of the belt. Length of belt $=3600 \mathrm{~mm}=0.36 \mathrm{~m}$

Velocity of the belt can therefore be found as, $\mathrm{V}_{\text {belt }}=l_{\text {belt }} / \mathrm{t}=0.06 \mathrm{~m} / \mathrm{s}=3.6 \mathrm{~m} / \mathrm{min}$

$(1 \mathrm{~m} / \mathrm{s}=60 \mathrm{~m} / \mathrm{min})$

The roller takes one complete revolution when the belt travels the distance equivalent to its length. The speed of the roller in RPM can be found as,

$$
\mathrm{RPM}_{\text {roller }}=\mathrm{v}_{\text {belt }} / \mathrm{d}_{\text {roller }}
$$$$
\text { Diameter of roller }=150 \mathrm{~mm}=0.15 \mathrm{~m}
$$

Therefore, $\mathrm{RPM}_{\text {roller }}=24 \mathrm{rpm}$

Consider the value of gear ratio to be 40 .

We know that, Gear Ratio $=\mathrm{RPM}_{\text {motor }} / \mathrm{RPM}_{\text {roller }}$

Thus, the rated RPM of motor is,

$$
\mathrm{RPM}_{\text {motor }}=960 \mathrm{rpm}
$$

2) Motor Torque

For finding the value of torque, we need to know the forces, which in turn are calculated from the mass of all components of the machine and the mass of material. The value of mass for all components is found in the table below by using the formula

Mass $=$ Volume $\times$ Density

Density of Mild Steel $=7.85 \mathrm{~g} / \mathrm{cm}^{3}$

- Mass of Belt:

Volume of belt $=l_{\text {belt }} \times b_{\text {belt }} \times h_{\text {belt }}=7200 \times 450 \times 10$

$$
=32400000 \mathrm{~mm}^{3}=32400 \mathrm{~cm}^{3}
$$

Mass of belt $=254340 \mathrm{~g}=254.34 \mathrm{~kg}$

- Mass of Roller:

Volume of roller $=\pi \times\left(\mathrm{r}_{\text {roller }}\right)^{2} \times 1_{\text {roller }}=\pi \times(75)^{2} \times 450$

$$
=7948125 \mathrm{~mm}^{3}=7948.125 \mathrm{~cm}^{3}
$$

Mass of roller $=62392.78125 \mathrm{~g}=62.393 \mathrm{~kg}$

Mass of both rollers $=124.786 \mathrm{~kg}$

- Mass of Slat Chain

Length of Slat Chain $=7.2 \mathrm{~m}$

Mass per unit length $=4.4 \mathrm{~kg} / \mathrm{m}$

(Standard factor of conversion)

Mass of chain $=31.68 \mathrm{~kg}$

- Mass of material $=100 \mathrm{~kg}$

Therefore, total mass of all components $=510.806 \mathrm{~kg}$

The total force to be pulled by the conveyor can be calculated by the free body diagrams given below where,

$\mathrm{m}=\mathrm{m}_{\text {material }}, \mathrm{M}=$ Total Mass of all components, $\Theta=$ $50^{\circ}$, Coefficient of friction between belt and material $=\mu_{1}=$ $0.15, \mathrm{~g}=9.81 \mathrm{~m} / \mathrm{s}^{2}$ 


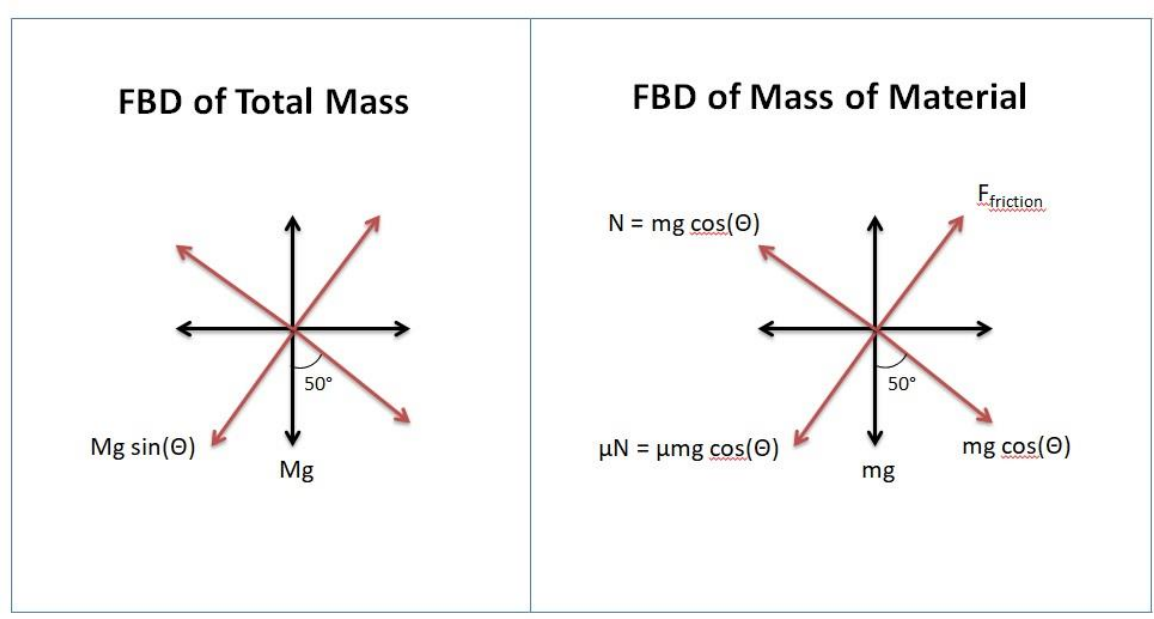

Fig. 5. Free Body Diagram of System

Therefore,

$$
\begin{aligned}
& \mathrm{F}_{1}=\mathrm{Mg} \sin (\Theta)+\mu_{1} \mathrm{mg} \cos (\Theta) \\
& \mathrm{F}_{1}=3931.861 \mathrm{~N}
\end{aligned}
$$

Considering a factor of safety of 1.5 , the total force can be thus calculated as,

$$
\begin{aligned}
& \mathrm{F}=\mathrm{F}_{1} \times \mathrm{FOS} \\
& \mathrm{F}=5897.792 \mathrm{~N}
\end{aligned}
$$

Torque is given by the formula,

$$
\begin{aligned}
\mathrm{T}_{\text {roller }}= & \mathrm{F} \times \mathrm{r}_{\text {roller }} \\
& \text { where, } \mathrm{r}_{\text {roller }}=75 \mathrm{~mm}=0.075 \mathrm{~m}
\end{aligned}
$$

Therefore, $\mathrm{T}_{\text {roller }}=442.334 \mathrm{~N}-\mathrm{m}$

We know that,

Gear Ratio $=\mathrm{T}_{\text {roller }} / \mathrm{T}_{\text {motor }}$

Thus, the rated torque of motor is,

$$
\mathrm{T}_{\text {motor }}=11.058 \mathrm{~N}-\mathrm{m}=11 \mathrm{~N}-\mathrm{m} \text { (approx.) }
$$

\section{3) Motor Power}

Power is given by the formula,

$$
\mathrm{P}_{\text {motor }}=\mathrm{T} \times \omega=\mathrm{T} \times[(2 \pi \times \mathrm{RPM}) / 60]
$$

Therefore, $\mathrm{P}_{\text {motor }}=1111.144 \mathrm{Watt}=1.111 \mathrm{~kW}=1.489 \mathrm{HP}$

Therefore, $\mathrm{P}_{\text {motor }}=1.5 \mathrm{HP}$

$$
(1 \mathrm{HP}=746 \mathrm{Watt}=0.746 \mathrm{~kW})
$$

\section{B. Selection of Pneumatic Cylinder}

The selection of dimensions of cylinder can be done on the basis of the formula

Push Force $=$ Discharge Pressure $\times$ Area of Cylinder

$$
\mathrm{F}_{\text {push }}=\mathrm{P}_{\text {discharge }} \times \mathrm{A}_{\text {cylinder }}
$$

Mass of the material to be pushed,

$$
\mathrm{m}_{\text {material }}=100 \mathrm{~kg}
$$

Mass of trolley can be calculated as,

Length of trolley $=1_{\text {trolley }}=700 \mathrm{~mm}$

Breadth of trolley $=b_{\text {trolley }}=600 \mathrm{~mm}$

Height of trolley $=h_{\text {trolley }}=450 \mathrm{~mm}$

Thickness of trolley $=\mathrm{t}_{\text {trolley }}=5 \mathrm{~mm}$

Total Surface Area of trolley $=\mathrm{A}_{\text {trolley }}=1_{\text {trolley }} \times \mathrm{h}_{\text {trolley }}+$

$b_{\text {trolley }} \times h_{\text {trolley }}+b_{\text {trolley }} \times 1_{\text {trolley }}{ }^{2} \times \mathrm{h}_{\text {trolley }}{ }^{2}$ ) $=1084299.5093$ $\mathrm{mm}^{2}$

Volume of trolley $=\mathrm{V}_{\text {trolley }}=\mathrm{A}_{\text {trolley }} \times \mathrm{t}_{\text {trolley }}$

$$
=5421497.5466 \mathrm{~mm}^{3}=5421.4975 \mathrm{~cm}^{3}(16)
$$

Density of Material $=\mathrm{d}_{\text {mildsteel }}=7.85 \mathrm{~g} / \mathrm{cm}^{3}$
Therefore, Mass of trolley $=\mathrm{m}_{\text {trolley }}=\mathrm{V}_{\text {trolley }} \times \mathrm{d}_{\text {mildsteel }}=$ $42558.756 \mathrm{~g}=43 \mathrm{~kg}$

$(1 \mathrm{~kg}=1000 \mathrm{~g})$

Therefore, total mass to be pushed by the cylinder,

$$
\mathrm{m}_{\text {total }}=\mathrm{m}_{\text {material }}+\mathrm{m}_{\text {trolley }}=143 \mathrm{~kg}
$$

Push force required will be equal to the frictional force between bottom surface of the trolley and the surface on which it is pushed.

Coefficient of friction $=\mu_{2}=0.5$

Acceleration due to gravity $=\mathrm{g}=9.81$

$\mathrm{F}_{\text {push }}=\mu_{2} \mathrm{mg}=701.415 \mathrm{~N}$

Discharge pressure of the cylinder which is selected is,

$$
\mathrm{P}_{\text {discharge }}=4 \mathrm{bar}=0.4 \mathrm{~N} / \mathrm{mm}^{2}
$$

Area of cylinder can be calculated as:

$$
\mathrm{A}_{\text {cylinder }}=\mathrm{F}_{\text {push }} / \mathrm{P}_{\text {discharge }}=1753.5375 \mathrm{~mm}^{2}
$$

Area of cylinder can be given by the formula:

$$
\text { Area of Cylinder }=3.14 *\left(D^{2}-d^{2}\right) / 4
$$

where, $\mathrm{D}=$ bore diameter, $\mathrm{d}=$ rod diameter

In standard cylinders available, Rod diameter $=20 \mathrm{~mm}$

Therefore, Bore diameter can be calculated as,

$$
\begin{aligned}
& \mathrm{D}^{2}=\left[\left(4^{*} \text { Area of cylinder }\right) / 3.14\right]+\mathrm{d}^{2} \\
& \mathrm{D}=51.321 \mathrm{~mm}
\end{aligned}
$$

Selecting from the standard sizes available,

Bore Diameter $=54 \mathrm{~mm}$.

The cylinder needs to push the trolley upto a required distance at which the barrel is to be loaded.

Therefore, stroke length of the cylinder should be equal to the distance through which the trolley travels. According to space considerations the barrel is located at 1 meter for the starting point.

Therefore stroke length of the cylinder,

$$
\mathrm{L}=1000 \mathrm{~mm}
$$




\section{IV.FINANCIAL ANALYSIS}

\section{A. Cost of Machine}

TABle II. CALCUlation of Cost OF Machine

\begin{tabular}{|c|c|c|}
\hline Component & $\begin{array}{l}\text { Price } \\
\text { (Rs.) }\end{array}$ & Remark \\
\hline Motor & 8500 & $1.5 \mathrm{HP}, 960 \mathrm{RPM}$ \\
\hline Gear Box & 10000 & Gear Ratio $=36$ \\
\hline $\begin{array}{l}\text { Pneumatic } \\
\text { Cylinder }\end{array}$ & 17000 & $\begin{array}{c}\text { Stroke Length }=1000 \mathrm{~mm} \text {, Bore } \\
\text { Diameter }=54 \mathrm{~mm}\end{array}$ \\
\hline Compressor & 40000 & Discharge Pressure $=4$ bar, $10 \mathrm{HP}$ \\
\hline Slat Belt \& Chain & 72000 & 14.4 meters belt \\
\hline Conveyor Roller & 18000 & \\
\hline $\begin{array}{l}\text { Pneumatic } \\
\text { Solenoid }\end{array}$ & 11000 & $5 / 2$ and $5 / 3$ Solenoid Valve \\
\hline Hooper & 52800 & $\begin{array}{l}440 \mathrm{~kg} \text { Mild Steel sheet of } 5 \mathrm{~mm} \\
\text { thickness }\end{array}$ \\
\hline Trolley & 5160 & $43 \mathrm{~kg}$ Mild Steel sheet of $5 \mathrm{~mm}$ thickness \\
\hline Load Cell & 25000 & Max Capacity $1500 \mathrm{kgf}$ \\
\hline SCADA & 15000 & \\
\hline Other Misc. & 20000 & \\
\hline TOTAL & 294460 & \\
\hline
\end{tabular}

\section{B. Labour Cost}

\begin{tabular}{|c|c|c|}
\hline Type & Manual & Automatic \\
\hline Total Labour & 6 & 2 \\
\hline Daily Wages & 450 & 450 \\
\hline No. of Shifts & 3 & 3 \\
\hline Daily Labour Cost & 8100 & 2700 \\
\hline Annual Labour Cost & 2430000 & 810000 \\
\hline
\end{tabular}

*(Considering 1 year has 300 working days)

\section{Total Annual Savings}

For Manual Loading,

Total Annual Cost $=$ Annual Labour Cost

$$
=\text { Rs. } 2430000
$$

For Automatic Loading,

Total Annual Cost $=$ Annual Labour Cost + Annual Power Consumption + Cost of Machine = Rs.1215017

Thus the total annual cost for automatic loading is approximately equal to $50 \%$ of manual loading annual cost.

Therefore, Total Annual Savings = Rs. 1214983

E. Break Even Time of Machine

The total cost incurred by manual and automatic loading can be classified into two parts: Fixed and Variable. Fixed cost includes the cos of the machine which is constant throughout, whereas, variable cost includes the costs incurred daily which are labour and electricity cost.

The total cost incurred upto ' $n$ ' days can be calculated by the formula,

Total cost $=$ Fixed Cost $+($ Variable cost per day $\times n)$ where, Fixed Cost $=$ Cost of Machine and Variable Cost $=$ Daily Labour Cost + Daily Electricity Cost

For Manual Loading,

Fixed Cost $=0$, Daily Electricity Cost $=0$

Therefore, Total Cost $=\mathrm{n} \times$ Daily Labour Cost $=\mathrm{n} \times 8100$

For Automatic Loading,

Fixed Cost $=$ Machine Cost $=$ Rs. 294460

Variable Cost per day = Daily Labour Cost + Daily

Electricity Cost $=$ Rs.2983.48 per day

\section{Power Consumption}

TABle V. CALCUlation of ANNUAL POWER CONSUMPTION

\begin{tabular}{|c|c|c|}
\hline Motor & & \\
\hline Power Rating & 1.5 & $\mathrm{HP}$ \\
\hline Operating time per cycle & 1.119 & $\mathrm{~kW}$ \\
\hline Cycle time & 2 & $\mathrm{mins}$ \\
\hline No. of Cycles/Hour & 6 & $\mathrm{mins}$ \\
\hline Operating Time per hour & 10 & cycles/hr \\
\hline & 20 & $\mathrm{mins}$ \\
\hline Power Consumption & 0.333 & hours \\
\hline & 0.373 & $\mathrm{~kW}-\mathrm{hr}$ \\
\hline Rate per Unit & 0.373 & $\mathrm{units}$ \\
\hline Electricity Cost per hour & 9.5 & $\mathrm{Rs}$ \\
\hline Electricity Cost per day & 3.544 & $\mathrm{Rs}$. \\
\hline & 85.044 & $\mathrm{Rs}$. \\
\hline
\end{tabular}

\begin{tabular}{|c|c|c|}
\hline Compressor & & \\
\hline Power Rating & 10 & $\mathrm{HP}$ \\
\hline Operating time per cycle & 7.46 & $\mathrm{~kW}$ \\
\hline Cycle time & 1 & $\mathrm{mins}$ \\
\hline No. of Cycles/Hour & 6 & $\mathrm{mins}$ \\
\hline Operating Time per hour & 10 & cycles/hr \\
\hline & 10 & $\mathrm{mins}$ \\
\hline Power Consumption & 0.167 & hours \\
\hline & 1.243 & $\mathrm{~kW}-\mathrm{hr}$ \\
\hline Rate per Unit & 1.243 & units \\
\hline Electricity Cost per hour & 9.5 & $\mathrm{Rs}$ \\
\hline Electricity Cost per day & 11.812 & Rs. \\
\hline Total Electricity Consumption Per Day & 283.48 & Rs. \\
\hline Annual Electricity Consumption & 1168.52 & Rs. \\
\hline
\end{tabular}

*(Considering 1 year has 300 working days)

Therefore, Total Cost $=294460+(2983.48 \times n)$

Considering that after ' $\mathrm{x}$ ' days the total manual loading cost will be equal to the total automatic loading cost. $\mathrm{x} \times 8100=294460+(2983.48 \times \mathrm{x})$ $\mathrm{x}=57.551=58$ days (approx.)

Therefore it can be said that after 58 days, the Automatic Loading Machine will start giving profits which will thus keep on increasing. This point is also known as break even time.

The break even time can also be found out graphically. Considering the total cost incurred in Manual and Automatic Loading for a span of 120 days. It can be seen that the breakeven time comes out to be approximately 60 days.

TABLE VI. COST INCURRED BY MANUAL AND AUTOMATIC LOADING FOR 120 DAYS

\begin{tabular}{|c|c|c|}
\hline Days & Manual & Automatic \\
\hline 20 & 162000 & 354130 \\
\hline 40 & 324000 & 413799 \\
\hline 60 & 486000 & 473469 \\
\hline 80 & 648000 & 533138 \\
\hline 100 & 810000 & 592808 \\
\hline 120 & 972000 & 652478 \\
\hline
\end{tabular}




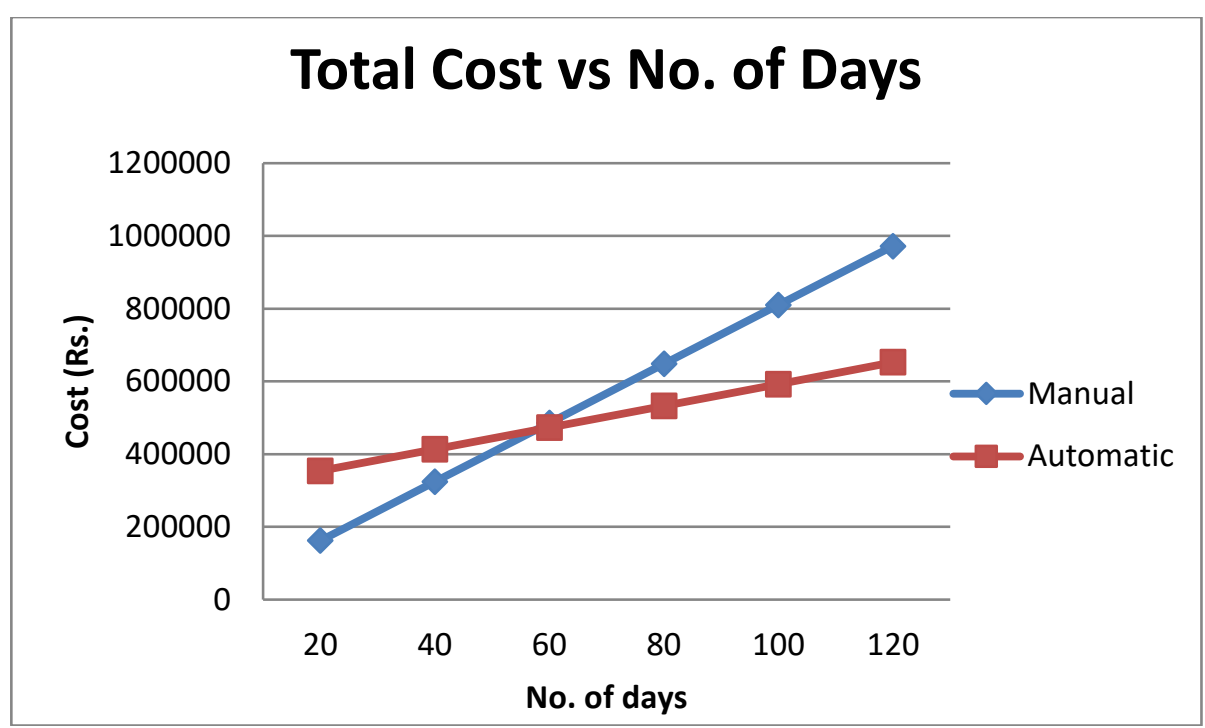

Fig. 9. Graph comparing cost incurred by Manual and Automatic Loading for 120 days

\section{COMPARISON BETWEEN MANUAL AND}

AUTOMATIC LOADING

TABLE VII. COMPARISON BETWEEN MANUAL AND AUTOMATIC LOADING

\begin{tabular}{|l|l|l|}
\hline Type of Loading & Manual & Automatic \\
\hline Weighing & Manual & Automatic \\
\hline Dependency on Labour & High & Very Low \\
\hline Power Consumption & Not required & Required \\
\hline Initial Investment & Low & High \\
\hline Long Term Costs & High & Low \\
\hline Error & Possible & None \\
\hline Efficiency & Low & High \\
\hline
\end{tabular}

\section{VI.CONCLUSION}

Excess labour can lead to decrease in the efficiency. Also the cost labour is increasing every year by approximately $10 \%$ due to increase in rate of inflation. Availability of labour is also going to be a major issue in near future. Therefore, we need to rely on some new machines to increase the efficiency and also reduce the cost.

The automatic loading machine used in electroplating industries for loading of barrel can be introduced to solve the above problems. It can be seen from this report that the machine starts giving profits within only 58 days of instalment. This will reduce the labour cost required resulting in increasing savings every year. Also the efficiency of the work increases. Thus, this machine can be a boost in the electroplating industry.

\section{REFERENCES}

[I] Canning, W. (2000). The Canning Handbook : Surface Finishing Technology (23rd ed.). New Delhi: CBS \& Distributors.

[II] Graham, A. K. (2000). Electroplating Engineering Handbook (Fourth ed.) (L. J. Durney, Ed.). India: CBS \& Distributors Pvt.

[III] Wang, S., Tang, R., Zhou, J., \& Zhou, H. (2011, August 16). Research on Automatic Electroplating Product Line's Scheduling System in Small Batch and Multi Types of Electroplating. Retrieved from https://www.scientific.net/AMR.317-319.621

[IV] Campbell, S. (2011, September 28). Guidelines for Selecting Pneumatic Cylinders. Retrieved from https://www.machinedesign.com/mechanical-motionsystems/pneumatics/article/21831605/guidelines-for-selectingpneumatic-cylinders

[V] Bch, B. (n.d.). Calculation methods - conveyor belts Content Retrieved from https://www.academia.edu/15526247/Calculation_methods_conveyo r_belts_Content

[VI] Forbo Siebling Service, n.d. Calculation Methods - Conveyor Belts. 